\title{
PREFERENSI DAN FREKUENSI KONSUMSI MAKANAN JAJANAN PADA ANAK SEKOLAH DASAR DI KECAMATAN CIJERUK, KABUPATEN BOGOR
}

\author{
(Preference and frequency of street food consumption among elementary school children at Cijeruk \\ Sub-district, Bogor District)
}

\author{
Leily Amalia ${ }^{1 *}$, Oktavianus Para Endro1, dan M. Rizal M. Damanik' \\ 'Departemen Gizi Masyarakat, FEMA, IPB
}

\begin{abstract}
This study aimed to analyze preference and consumption frequency of street foods among elementary school children at Cijeruk sub-district, Bogor District. The design used as survey method at three elementary schools at the area, namely SDN 01 Palasari, SDN 02 Palasari, dan SDN 01 Cipicung. The data was collected in April until June 2012. The subjects of study were 80 students at $4^{\text {th }}$ and $5^{\text {th }}$ grade of elementary school, consisted of 40 boys and 40 girls. Data collection was done by observation and interview to students. The data collected were: family characteristics, individual characteristics, nutrition knowledge, preference and the reasons, and consumption frequency of the street foods. The results showed that family size of subjects mostly (65.5\%) categorized as moderate (consisted of 4-6 persons). Both father's and mother's education level were categorized as low, namely graduated from elementary shools (42.5\% each) and even ungraduated of elementary schools $(31.3 \%$ and 23.8\%). In general, family income per capita was categorized as poor (51.3\%) and almost poor (40.0\%), with average of $R p 183063$ which was lower than poverty line of West Java Province at sub-urban areas (Rp 210 000). The average of pocket money of subjects was Rp 2293.7. Nutrition knowledge of subjects was generally categorized as moderate (47.5\%). All of subjects stated that they like street foods. The order of street foods from high to low prefered by subjects was fruit, beverages, fried food, cakes, dried snack, and dish foods. The primary preference reason of subjects on street foods was taste (minimal 60\% for each food group). The order of street foods which highly to rarely consumed per week was fried food (7.0 times), beverages (6.7 times), cakes (6.3 times), dish foods (6.2 times), salted-dried snacks (5.3 times), and fruits (5.0 times).
\end{abstract}

Key words: consumption frequency, preference, reasons of preference, street food

\section{ABSTRAK}

Penelitian ini bertujuan untuk menganalisis preferensi dan frekuensi makanan jajanan pada anak SD di Kecamatan Cijeruk, Kabupaten Bogor. Penelitian dilakukan dengan metode survey, di tiga Sekolah Dasar di Kecamatan Cijeruk, Kabupaten Bogor, yaitu SDN 01 Palasari, SDN 02 Palasari, dan SDN 01 Cipicung. Pengambilan data dilakukan pada bulan April hingga Juni 2012. Subjek penelitian adalah siswa kelas 4 dan kelas 5 SD, berjumlah 80 siswa, terdiri dari 40 siswa laki-laki dan 40 siswa perempuan. Penarikan subjek dilakukan secara purposive proposional dari populasi siswa di ketiga SD terpilih. Data dikumpulkan dengan cara pengamatan dan wawancara kepada siswa, terdiri dari karakteristik keluarga, karakteristik individu, pengetahuan gizi, preferensi dan alasannya, serta frekuensi konsumsi makanan jajanan. Besar keluarga subjek sebagian besar (65.5\%) tergolong sedang (4-6 orang). Pendidikan ayah dan ibu subjek sebagian besar tamatan SD (42.5\%) dan tidak tamat SD (31.3\% dan 23.8\%). Pendapatan keluarga per kapita subjek umumnya tergolong miskin (51.3\%) dan $40.0 \%$ termasuk kategori hampir miskin. Rata-rata pendapatan keluarga per kapita adalah Rp 183 063, lebih rendah dari garis kemiskinan Jawa Barat pedesaan (Rp 210 000). Rata-rata uang jajan subjek adalah Rp 2 293.7. Pengetahuan gizi subjek umumnya (47.5\%) berada pada kategori sedang. Urutan makanan jajanan yang paling disukai hingga agak disukai adalah buah, minuman, makanan gorengan, kue, keringan asin, dan jajanan sepinggan. Alasan utama subjek dalam menyukai semua kelompok makanan jajanan adalah rasa (minimal 60\%). Urutan kelompok jajanan dengan frekuensi konsumsi dalam seminggu dari tertinggi hingga terendah adalah makanan digoreng (7.0 kali), minuman (6.7 kali), kue (6.3 kali), jajanan sepinggan (6.2 kali), keringan asin (5.3 kali), dan buah (5.0 kali).

Kata kunci: alasan suka, frekuensi konsumsi, makanan jajanan, preferensi

"Korespondensi: Departemen Gizi Masyarakat, Fakultas Ekologi Manusia (FEMA), Institut Pertanian Bogor, Jl. Raya Darmaga, 16680. Tel: 0251 - 8621363, Fax: 0251 - 8622276; Email: leilyamalia@yahoo.com 


\section{PENDAHULUAN}

Hasil penelitian Proverawati et al. (2008) tentang preferensi makanan anak TK di Purwokerto menunjukkan bahwa makanan yang disukai anakanak adalah makanan kaya karbohidrat dan protein hewani. Hal serupa juga ditunjukkan dari hasil penelitian Rodrigo et al. (2003) di Spanyol yang menyatakan bahwa anak-anak di Spanyol cenderung menyukai makanan sumber karbohidrat dan protein dibandingkan makanan sumber serat.

Di usia kanak-kanak, makanan ringan merupakan salah satu bentuk makanan yang dikonsumsi dalam jumlah banyak dan memberikan kontribusi yang cukup tinggi terhadap kecukupan energi dan zat gizi. Menurut Syarifah (2010), konsumsi makanan jajanan pada anak dapat memberikan kontribusi $30.0 \%$ dan $22.3 \%$ terhadap kecukupan energi dan protein. Tambahan energi pada saat sekolah bisa berdampak positif kepada anak sekolah. Anak bisa menjadi tetap aktif karena kadar gula darah tetap terjaga dengan baik. Dengan demikian makanan jajanan, khususnya jajanan yang sehat, dapat bermanfaat dan berdampak baik bagi kesehatan.

Menurut Proverawati et al. (2008), anak-anak sering sekali bermasalah dalam mengonsumsi makanan yang memenuhi kebutuhan gizi karena anakanak cenderung memilih makanan tertentu yang disukai saja. Karakteristik rasa, warna, bentuk yang lucu dan menarik, seringkali menjadi faktor penentu anak dalam memilih makanan. Adapun faktor gizi seringkali tidak menjadi faktor pertimbangan. Hal ini tentu akan berpengaruh terhadap kecukupan dan kebutuhan gizi anak yang sedang dalam masa pertumbuhan yang pesat.

Berdasarkan pertimbangan tersebut, peneliti menyadari jajanan memiliki peran dalam membantu mencukupi kebutuhan energi dan zat gizi anak. Untuk itu dinilai perlu suatu penelitian yang menganalisis preferensi dan frekuensi makanan jajanan anak, khususnya anak sekolah dasar.

Tujuan umum dari penelitian ini adalah untuk menganalisis preferensi dan frekuensi konsumsi makanan jajanan pada anak SD di Kecamatan Cijeruk, Kabupaten Bogor.

\section{METODE}

\section{Desain, Tempat, dan Waktu}

Penelitian dilakukan dengan metode survei, di tiga SD di Kec. Cijeruk, Kab. Bogor, yaitu SDN 01 dan 02 Palasari, serta SDN 01 Cipicung. Pengambilan data dilakukan pada bulan April-Juni 2012.

\section{Jumlah dan Cara Penarikan Subjek}

Subjek dalam penelitian adalah siswa kelas 4 dan kelas 5 sekolah dasar. Siswa kelas 4 dan 5 dipilih dengan pertimbangan bahwa pada usia tersebut anak sudah cukup matang dalam berpikir sehingga bisa memberikan respon jawaban secara mandiri. Siswa kelas 6 SD tidak dipilih karena pada masa tersebut biasanya siswa sudah disibukkan dengan kegiatan belajar tambahan sebagai persiapan ujian akhir dan kelulusan. Penarikan subjek dilakukan secara purposive propotional menurut jenis kelamin dari jumlah populasi siswa di ketiga 3 SD terpilih. Subjek seluruhnya berjumlah 80 siswa, terdiri dari 40 siswa laki-laki dan 40 siswa perempuan.

\section{Jenis dan Cara Pengumpulan Data}

Data yang dikumpulkan berupa data sekunder dan data primer. Data sekunder terdiri dari data nama, jenis kelamin, dan jumlah siswa setiap SD terpilih yang didapatkan dari pihak Tata Usaha Sekolah.

Data primer terdiri dari jenis-jenis makanan yang dijual di lingkungan sekolah (kantin, warung, dan penjaja makanan jajanan), karakteristik keluarga subjek (besar keluarga, pendapatan keluarga, dan tingkat pendidikan orang tua), karakteristik individu (umur dan uang jajan anak), pengetahuan gizi subjek, data preferensi, alasan suka dan frekuensi konsumsi makanan jajanan. Data primer tentang jenis-jenis makanan dikumpulkan dengan cara pengamatan terhadap penjual makanan di lingkungan sekolah. Adapun data primer lainnya dikumpulkan dengan teknik wawancara kepada siswa dengan menggunakan kuesioner.

Besar keluarga diketahui berdasarkan jumlah anggota keluarga yang tinggal dalam satu rumah. Pendapatan keluarga adalah penghasilan yang didapatkan oleh seluruh anggota keluarga. Data pengetahuan gizi diambil dengan menggunakan 20 pertanyaan mengenai makanan jajanan, fungsi zat gizi, dan sumber zat gizi. Setiap pertanyaan diberikan dalam bentuk pilihan ganda dengan tiga pilihan jawaban. Menurut Khomsan (2000) dengan menanyakan 20 butir pertanyaan tentang gizi dengan tingkat kesulitan yang disesuaikan dengan tingkatan umur, sudah bisa mengetahui tingkat pengetahuan gizi seseorang.

Data jenis makanan jajanan yang dijual di lingkungan sekolah secara umum terdapat 28 jenis, masing-masing bisa terdiri dari lebih dari satu rasa. Berdasarkan jenisnya, jajanan-jajanan tersebut kemudian dikelompokkan menjadi 6 kelompok, yaitu jajanan sepinggan (terdiri dari 5 jenis makanan: 
nasi uduk, nasi goreng, bakso, bihun goreng, dan cilok), makanan jajanan digoreng (terdiri dari 5 jenis makanan: bakso goreng, batagor, chicken nugget, cireng aneka rasa, beragam gorengan (tempe goreng, bakwan, tahu goreng, risoles), keringan asin (keripik, kacang goreng, pilus, dan snack turbo), kue basah dan kering (5 jenis: donat/onde-onde, sus, biskuit/kue coklat, wafer, dan biskuit), minuman (es lilin dan sejenisnya, es susu, es teh, es jeruk, dan agar-agar), serta aneka buah (kedondong, nenas, mangga, pisang).

Data preferensi subjek dikumpulkan sebagai "sangat tidak suka" (nilai 1), "tidak suka” (nilai 2), “biasa” (nilai 3), "suka” (nilai 4), dan "sangat suka” (nilai 5). Alasan subjek menyukai jajanan dikelompokkan berdasarkan karakteristik jajanan, yaitu harga, rasa, karakteristik organoleptik lainnya (bentuk, warna, tekstur), dan kandungan gizi. Data frekuensi konsumsi makanan jajanan diperoleh dari kebiasaan makan dan jajan siswa terhadap makanan jajanan, bisa sebagai konsumsi per hari, per minggu, ataupun per bulan.

\section{Pengolahan dan Analisis Data}

Sebelum diolah, data terlebih dahulu melalui tahapan proses editing, coding, scoring, entry, dan cleaning. Setelah itu data kemudian diolah berdasarkan pengkategorian menurut acuan standar tertentu dengan menggunakan Microsoft Excel 2007. Data hasil olahan tersebut kemudian dianalisis secara deskriptif untuk penarikan kesimpulan.

Besar keluarga dikelompokkan sebagai "kecil" jika jumlah anggota keluarga $\leq 4$ orang, "sedang" jika berjumlah 5-6 orang, dan "besar" jika berjumlah $\geq 7$ orang (Hurlock 2004). Pendapatan keluarga subjek diolah dan dibagi menurut jumlah anggota keluarga, sehingga didapatkan pendapatan per kapita keluarga. Pendapatan tersebut kemudian dikelompokkan menjadi tiga kategori tingkat kesejahteraan berdasarkan angka Garis Kemiskinan (GK) Jawa Barat, yaitu "miskin" jika pendapatan per kapita <1GK, "hampir miskin" jika pendapatan per kapita antara 1 dan 2 GK, dan "menengah ke atas" jika pendapatan perkapita >2 GK (Puspitawati 2010). Garis Kemiskinan yang digunakan adalah garis kemiskinan Jawa Barat di pedesaan, yaitu Rp 210 000/kapita/bulan (BPS Jawa Barat 2012).

Umur subjek dikelompokkan berdasarkan umur standar anak kelas 4 dan 5, yaitu 10-11 tahun, sehingga kategori umur yang ditetapkan adalah $<10$ tahun, 10-11 tahun, dan $>11$ tahun. Besar uang jajan subjek dikategorikan berdasarkan sebaran data menjadi rendah (<Rp 2 000), sedang (Rp
2 000-Rp 4 000), dan tinggi ( $\geq R p 4000$ ). Penilaian untuk menganalisis tingkat pengetahuan gizi subjek diukur berdasarkan skor dari jawaban atas 20 pertanyaan yang diajukan yang secara total diberi skor antara 0-100. Skor kemudian dikelompokkan kedalam tiga kategori yaitu "kurang" jika skor<60, "sedang" jika skor antara 60 dan 80, dan "baik" jika skor>80 (Khomsan 2000).

Data preferensi, alasan suka, dan frekuensi konsumsi makanan jajanan diperoleh berdasarkan jawaban tingkat kesukaan, alasan suka, dan frekuensi konsumsi subjek terhadap beragam makanan jajanan yang dijual di sekitar sekolah. Data preferensi makanan kemudian diolah untuk mendapatkan nilai modus subjek, yaitu tingkat kesukaan yang paling sering muncul untuk setiap jenis kelompok jajanan. Selain itu dihitung pula persentase subjek berdasarkan tingkat kesukaan untuk menganalisis jenis makanan yang paling disukai subjek. Data frekuensi jajan diperoleh dari kebiasaan jajan siswa per hari, per minggu, atau per bulan kemudian dikonversi kedalam satuan per minggu untuk memudahkan dalam perbandingan tingkat frekuensi konsumsi jajanan subjek antar makanan.

\section{HASIL DAN PEMBAHASAN}

\section{Karakteristik Orang Tua}

Jumlah anggota keluarga menentukan jumlah dan pola konsumsi makanan, barang maupun jasa. Besar keluarga subjek sebagian besar tergolong kategori sedang (65.5\%), yaitu jumlah anggota dalam keluarga lima hingga enam orang. Penelitian Mukherjee et al. (2008) menunjukkan bahwa anggota keluarga di atas lima orang menunjukkan adanya hubungan yang signifikan dengan kurangnya berat badan. Semakin banyak anggota keluarga maka semakin besar biaya yang dibutuhkan untuk memenuhi kebutuhan barang konsumsi, termasuk pangan. Sementara itu, jika tidak didukung dengan peningkatan pendapatan, maka semakin banyak anggota keluarga maka semakin besar penyusutan dalam pemenuhan kebutuhan pangan.

Pendidikan ayah subjek umumnya tergolong rendah, yaitu sebagian besar tamatan SD (42.5\%) dan bahkan tidak tamat SD (31.3\%). Demikian juga halnya dengan pendidikan ibu, sebagian besar hanya tamat SD (42.5\%) dan tidak tamat SD (23.8\%) (Tabel 1). Pendidikan orang tua yang rendah, terutama ibu, akan berpengaruh terhadap praktek gizi dalam rumah tangga, termasuk dalam hal penyediaan dan pengarahan ibu untuk konsumsi pangan anggota keluarga, termasuk jajan anak. Penelitian 
Tabel 1. Sebaran Subjek berdasarkan Karakteristik Orang Tua

\begin{tabular}{|c|c|c|}
\hline Karakteristik Orang Tua & $\mathrm{n}=80$ & $\%$ \\
\hline \multicolumn{3}{|l|}{ Besar Keluarga } \\
\hline Kecil ( $\leq 4$ orang) & 17 & 21.3 \\
\hline Sedang (5-6 orang) & 52 & 65.0 \\
\hline Besar ( $\geq 7$ orang) & 11 & 13.8 \\
\hline \multicolumn{3}{|l|}{ Pendidikan Ayah } \\
\hline$\overline{\text { Tidak Tamat SD }}$ & 25 & 31.3 \\
\hline SD/Setara & 34 & 42.5 \\
\hline SMP/Setara & 10 & 12.5 \\
\hline SMA/Setara & 10 & 12.5 \\
\hline Perguruan Tinggi & 1 & 1.3 \\
\hline \multicolumn{3}{|l|}{ Pendidikan lbu } \\
\hline$\overline{\text { Tidak Tamat SD }}$ & 19 & 23.8 \\
\hline SD/Setara & 34 & 42.5 \\
\hline SMP/Setara & 8 & 10 \\
\hline SMA/Setara & 17 & 21.3 \\
\hline Perguruan Tinggi & 2 & 2.5 \\
\hline \multicolumn{3}{|l|}{ Pendapatan keluarga per kapita } \\
\hline Miskin $(<$ Rp 210 000/kap/bln) & 41 & 51.3 \\
\hline Hampir miskin (Rp 210 000-Rp 420 000/kap/bln) & 32 & 40.0 \\
\hline Menengah ke atas (>Rp 420 000/kap/bln) & 7 & 8.7 \\
\hline Rata-rata \pm SD & Rp 183 & 101312.9 \\
\hline
\end{tabular}

Osei et al. (2010) menunjukkan bahwa praktek gizi ibu menjadi faktor penting dalam penentuan kebutuhan gizi dan status gizi anak.

Pendidikan orang tua yang rendah berdampak pada tingkat pendapatan keluarga subjek yang tergolong rendah. Semakin tinggi tingkat pendidikan orang tua maka semakin besar peluang untuk mendapatkan pekerjaan dengan penghasilan yang tinggi, demikian juga sebaliknya. Bedasarkan pendapatan keluarga per kapita, subjek umumnya berada pada kategori miskin, yaitu sebanyak 51.3\% dan 40.0\% termasuk kategori hampir miskin (Tabel 1). Ratarata pendapatan keluarga per kapita adalah Rp 183 063 \pm Rp 101 313, dan nilai ini lebih rendah dari garis kemiskinan Jawa Barat pedesaan (Rp 210 000). Dengan demikian, secara rata-rata, keadaan ekonomi keluarga subjek masih tergolong miskin.

\section{Karakteristik Subjek}

Proporsi jenis kelamin subjek dalam penelitian ini telah diatur dalam tahapan penarikan subjek yang menggunakan teknik proportional sampling sehingga jumlah subjek perempuan dan laki-laki adalah setara, masing-masing 40 siswa. Usia subjek umumnya antara 10-11 tahun (70\%). Uang jajan subjek tergolong cukup untuk keperluan jajan di perdesaan, yaitu umumnya antara Rp 2000 dan Rp 4 000, sebanyak 53.8\%. Rata-rata uang saku subjek adalah Rp2 293.7ェ913.0 (Tabel 2).

Besar uang saku subjek pada penelitian ini lebih rendah dari uang saku siswa di SDN Lawanggintung Kota Bogor yang sebagian besar (88.0\%) me- nerima uang saku antara Rp 2 800-Rp 7000 (Syafitri et al. 2009) ataupun dibandingkan rata-rata uang saku siswa di SD Bina Insani, Kota Bogor yang mencapai Rp 7470 (Deni \& Dwiriani 2009). Hal ini bisa dipahami karena keluarga subjek umumnya merupakan keluarga miskin (51\%) dan hampir miskin (40\%) (Tabel 1).

Tabel 2. Sebaran Subjek berdasarkan Karakteristik Individu

\begin{tabular}{lcc}
\hline \multicolumn{1}{c}{ Karakteristik Subjek } & $\mathrm{n}=\mathbf{8 0}$ & $\%$ \\
\hline Jenis Kelamin & & \\
Laki-laki & 40 & 50 \\
Perempuan & 40 & 50 \\
\hline Umur & 0 & 0 \\
$<10$ tahun & 56 & 70 \\
10-11 tahun & 24 & 30 \\
$>11$ tahun & 31 & 38.8 \\
\hline Uang Jajan (Rupiah) & 43 & 53.8 \\
$<2000$ & 6 & 7.5 \\
2000-<4000 & Rp 2 293.7 \pm 913.0 \\
$\geq 4000$ &
\end{tabular}

\section{Pengetahuan Gizi Subjek}

Pada dasarnya siswa kelas 4 dan 5 SD sudah mendapatkan materi tentang gizi pada pelajaran IPA di sekolahnya. Dengan demikian analisis terhadap pengetahuan gizi subjek merupakan analisis terhadap pemahaman subjek atas materi yang telah mereka terima di bangku sekolah. Pengetahuan gizi subjek umumnya termasuk cukup baik, yaitu sebanyak $47.5 \%$ berada pada kategori sedang, dan $16.3 \%$ 
Tabel 3. Sebaran Subjek berdasarkan Pengetahuan Gizi

\begin{tabular}{lcc}
\hline Kategori Pengetahuan Gizi & $\mathrm{n}=80$ & $\%$ \\
\hline Baik (skor $>80)$ & 13 & 16.3 \\
Sedang (skor 60-80) & 38 & 47.5 \\
Buruk (skor $<60)$ & 29 & 36.3 \\
\hline Rata-rata \pm SD & $64.3 \pm 17.6$ \\
\hline
\end{tabular}

berada pada tergolong kategori baik. Meskipun demikian, masih terdapat $36.3 \%$ subjek yang tergolong berpengetahuan gizi buruk (Tabel 3). Hasil ini relatif sama dengan hasil penelitian Deni dan Dwiriani (2009) yang menganalisis pengetahuan gizi anak SD di salah satu SD di Kota Bogor, yang menunjukkan bahwa tingkat pengetahuan gizi subjek umumnya berkategori sedang (43.8\%) dan hanya $16.2 \%$ yang berkategori baik. Materi yang ditanyakan dalam kuesioner adalah materi umum yang disesuaikan dengan tingkat pemahaman anak SD. Ditinjau dari jawaban yang diberikan atas pertanyaan seputar gizi yang diajukan, subjek umumnya telah memahami pengertian zat gizi ( $91.3 \%$ menjawab benar), zat gizi pada minyak goreng (86.3\%) dan fungsi kalsium bagi tubuh (81.3\%). Adapun pertanyaan gizi yang cenderung dijawab salah dan hanya sedikit yang menjawab benar adalah perta-nyaan mengenai zat gizi sumber tenaga (38.8\% yang menjawab benar), sumber pembangun $(31.3 \%)$ dan pengertian makanan (40\%) (Tabel 4). Berdasarkan jawaban tersebut, tampaknya siswa masih terbatas pemahamannya mengenai jenis-jenis makanan yang merupakan sumber zat gizi.

\section{Preferensi dan Alasan Kesukaan terhadap Makan- an Jajanan \\ Nilai modus preferensi subjek terhadap semua} kelompok makanan adalah suka dan sangat suka. Kelompok makanan yang umumnya "disukai" adalah makanan sepinggan, keringan asin, kue basah dan kering, serta minuman. Adapun kelompok makanan yang umumnya "sangat disukai" adalah makanan digoreng dan buah. Meskipun demikian, jika dilihat berdasarkan sebaran subjek dengan persentase tertinggi hingga terendah yang menilai suka dan sangat suka, urutan makanan jajanan tersebut adalah buah, minuman, makanan gorengan, keringan asin, kue, dan jajanan sepinggan (Tabel 5).

Alasan utama subjek menyukai makanan jajanan adalah rasa dan harga (Tabel 6). Pada semua kelompok jajanan, minimal $60 \%$ subjek menjadikan rasa sebagai alasan utama mereka dalam menyukai jajanan. Hal ini dapat dipahami karena masa kanakkanak adalah masa yang cenderung mencari kesenangan, khususnya merasakan rasa makanan yang enak di lidah, sehingga rasa menjadi faktor utama mereka dalam memilih makanan. Adapun alasan harga, kemungkinan besar karena uang saku subjek yang terbatas, yaitu rata-rata Rp 2 293.8. Dengan uang saku sejumlah tersebut, maka anak akan menyesuaikan pemilihan makanan jajanan dengan

Tabel 4. Sebaran Subjek berdasarkan Jawaban Pengetahuan Gizi yang Benar

\begin{tabular}{clcc}
\hline No & \multicolumn{1}{c}{ Pertanyaan } & $\mathbf{n}$ & $\%$ \\
\hline 1 & Pengertian zat gizi & 73 & 91.3 \\
2 & Pengertian makanan & 32 & 40.0 \\
3 & Zat gizi sumber tenaga & 31 & 38.8 \\
4 & Zat gizi sumber pem bangun & 25 & 31.3 \\
5 & Zat gizi pengatur fungsi dan kerja organ tubuh & 38 & 47.5 \\
6 & Kebutuhan air putih per hari & 42 & 52.5 \\
7 & Zat gizi pada nasi, mi, dan roti & 44 & 55.0 \\
8 & Zat gizi pada mentega dan minyak goreng & 69 & 86.3 \\
9 & Zat gizi pada jambu biji dan kedondong & 65 & 81.3 \\
10 & Pengertian makanan jajanan & 44 & 55.0 \\
11 & Makanan camilan termasuk kedalam makanan & 57 & 71.3 \\
12 & Jenis makanan jajanan kelom pok camilan & 58 & 72.5 \\
13 & Contoh makanan jajanan sumber energi & 32 & 40.0 \\
14 & Contoh makanan jajanan sumber protein & 53 & 66.3 \\
15 & Contoh makanan jajanan sumber air & 77 & 96.3 \\
16 & Penyakit akibat makanan jajanan tidak sehat & 70 & 87.5 \\
17 & Vitamin pencegah sariawan & 63 & 78.8 \\
18 & Fungsi kalsium dalam tubuh & 65 & 81.3 \\
19 & Gondok akibat kekurangan iodium & 48 & 60.0 \\
20 & Akibat kurang konsumsi vitamin A & 43 & 53.8 \\
\hline
\end{tabular}


Tabel 5. Sebaran Subjek berdasarkan Tingkat Kesukaan terhadap Makanan Jajanan menurut Kelompok Jajanan (\%)

\begin{tabular}{|c|c|c|c|c|c|c|c|c|c|c|c|}
\hline \multirow{2}{*}{ Kelompok jajanan } & \multirow{2}{*}{$\begin{array}{c}\text { Jml } \\
\text { jajanan }\end{array}$} & \multicolumn{2}{|c|}{ Sangat tidak suka } & \multicolumn{2}{|c|}{ Tidak suka } & \multicolumn{2}{|c|}{ Biasa } & \multicolumn{2}{|c|}{ Suka } & \multicolumn{2}{|c|}{ Sangat suka } \\
\hline & & $\mathrm{n}$ & $\%$ & $\mathrm{n}$ & $\%$ & $\mathrm{n}$ & $\%$ & $\mathrm{n}$ & $\%$ & $\mathrm{n}$ & $\%$ \\
\hline Jajanan sepinggan & 5 & 4 & 1.0 & 19 & 4.8 & 94 & 23.5 & 142 & 35.5 & 141 & 35.3 \\
\hline Makan an digoreng & 5 & 4 & 1.0 & 17 & 4.3 & 72 & 18.0 & 150 & 37.5 & 157 & 39.3 \\
\hline Keringan asin & 4 & 8 & 2.5 & 9 & 2.8 & 60 & 18.8 & 137 & 42.8 & 106 & 33.1 \\
\hline Kue basah \& kering & 5 & 10 & 2.5 & 20 & 5.0 & 71 & 17.8 & 160 & 40.0 & 139 & 34.8 \\
\hline Minuman & 5 & 4 & 1.0 & 8 & 2.0 & 63 & 15.8 & 163 & 40.8 & 162 & 40.5 \\
\hline Buah & 4 & 5 & 1.6 & 12 & 3.8 & 42 & 13.1 & 127 & 39.7 & 134 & 41.9 \\
\hline
\end{tabular}

Tabel 6. Sebaran subjek berdasarkan alasan menyukai makanan jajanan menurut kelompok jajanan (\%)

\begin{tabular}{|c|c|c|c|c|c|c|c|c|c|}
\hline \multirow{2}{*}{ Kelompok jajanan } & \multirow{2}{*}{ Jml jajanan } & \multicolumn{2}{|c|}{ Harga } & \multicolumn{2}{|c|}{ Rasa } & \multicolumn{2}{|c|}{ Organoleptik lain* } & \multicolumn{2}{|c|}{ Kandungan gizi } \\
\hline & & $\mathrm{n}$ & $\%$ & $\mathrm{n}$ & $\%$ & $n$ & $\%$ & $n$ & $\%$ \\
\hline Jajanan sepinggan & 5 & 96 & 24.0 & 245 & 61.3 & 34 & 8.5 & 25 & 6.3 \\
\hline Makan an digoreng & 14 & 109 & 27.3 & 238 & 59.5 & 33 & 8.3 & 20 & 5.0 \\
\hline Keringan asin & 5 & 63 & 19.7 & 215 & 67.2 & 42 & 13.1 & 0 & 0.0 \\
\hline Kue basah \& kering & 10 & 102 & 25.5 & 255 & 63.8 & 38 & 9.5 & 5 & 1.3 \\
\hline Minuman & 7 & 51 & 12.8 & 287 & 71.8 & 54 & 13.5 & 8 & 2.0 \\
\hline Buah & 4 & 18 & 5.6 & 276 & 86.3 & 18 & 5.6 & 8 & 2.5 \\
\hline
\end{tabular}

*meliputi : bentuk, tekstur, warna

ketersediaan uang yang mereka miliki. Sebaliknya, alasan manfaat gizi sangat jarang dijadikan alasan, yaitu hanya $0-6 \%$ subjek yang menjadikannya alasan menyukai kelompok jajanan. Kondisi fisik yang cenderung sehat dan pengetahuan gizi yang masih terbatas kemungkinan menjadi penyebab subjek tidak menjadikan aspek gizi sebagai alasan kesukaan.

\section{Frekuensi Konsumsi Makanan Jajanan}

Jika dibandingkan antara Tabel 7 dan Tabel 5, terlihat bahwa urutan frekuensi konsumsi subjek terhadap makanan jajanan tidak sejalan dengan tingkat kesukaan. Hal ini bisa terjadi karena dalam membeli dan mengonsumsi makanan jajanan harus didukung juga oleh ketersediaan uang jajan yang dimiliki subjek. Urutan kelompok jajanan dengan frekuensi konsumsi tertinggi hingga terendah adalah makanan digoreng, minuman, kue, jajanan sepinggan, dan buah.

Makanan digoreng seperti bakso goreng, tempe goreng, chicken nugget, dan cireng, merupakan makanan yang paling sering dikonsumsi anak, yaitu rata-rata dikonsumsi subjek 7 kali per minggu, atau sekitar 1.25 kali per makanan (ada 5 jenis) dalam seminggu. Sebagaimana dinyatakan sebelumnya, umumnya subjek menyukai makanan digoreng karena rasa yang sesuai dengan selera (59.5\%). Meskipun demikian, dari unsur harga, makanan digoreng ini dipilih tertinggi (27.3\%) dibandingkan kelompok makanan lain. Gorengan merupakan makanan yang gurih, umumnya biasa dikonsumsi dengan tambahan cabe rawit atau sambal. Tambahan bumbu pedas ini seringkali menjadikan seseorang merasa sedikit ketagihan. Di samping itu, makanan digoreng dijual dengan harga murah, yaitu sekitar Rp300/potong, sehingga memungkinkan bagi subjek untuk membeli makanan digoreng setiap hari karena terjangkau dengan uang saku yang ada.

Kelompok jajanan yang paling jarang dikonsumsi adalah buah, yaitu rata-rata dikonsumsi 5.0 kali per minggu. Jika dibandingkan dengan Tabel 6 di atas, alasan rasa merupakan alasan yang paling banyak dipilih oleh subjek, yaitu $86 \%$, tetapi alasan harga merupakan alasan yang paling sedikit dipilih oleh subjek (5.6\%). Dengan demikian, diduga sub-

Tabel 7. Sebaran Subjek berdasarkan Frekuensi Konsumsi Makanan Jajanan menurut Kelompok Jajanan Dalam Seminggu (kali)

\begin{tabular}{lccc}
\hline \multicolumn{1}{c}{ Kelompok jajanan } & $\begin{array}{c}\text { Jumlah } \\
\text { jajanan }\end{array}$ & $\begin{array}{c}\text { Rata-rata } \\
\text { Frekuensi Konsumsi/mg }\end{array}$ & $\begin{array}{c}\text { Rata-rata Frekuensi Konsumsi/ } \\
\text { Makanan/mg }\end{array}$ \\
\hline Jajanan sepinggan & 5 & 6.24 & 1.25 \\
Makanan gorengan & 5 & 6.96 & 1.39 \\
Keringan asin & 4 & 5.34 & 1.33 \\
Kue basah \& kue kering & 5 & 6.34 & 1.27 \\
Minuman & 5 & 6.67 & 1.33 \\
Buah & 4 & 4.94 & 1.24 \\
\hline Total & 28 & 36.49 & 7.81 \\
\hline
\end{tabular}


jek menjadi relatif jarang mengonsumsi buah karena harga yang relatif lebih mahal dibandingkan makanan lain.

Kebiasaan konsumsi jajanan sepinggan subjek pada penelitian ini ( 6.2 kali per minggu) lebih sering dibandingkan dengan hasil penelitian Syafitri (2009) yang menunjukkan frekuensi konsumsi jajanan sepinggan anak SD di Lawanggintung, Kota Bogor, adalah hanya 3-5 kali per minggu. Lebih seringnya anak mengonsumsi jajanan sepinggan diduga anak cenderung tidak sarapan di rumahnya.

\section{KESIMPULAN}

Status sosial ekonomi keluarga subjek tergolong rendah, terlihat dari tingkat pendidikan ayah maupun ibu subjek yang umumnya tamat SD dan tidak tamat SD, serta pendapatan rata-rata/kapita/ bulan Rp 183083 yang di bawah garis kemiskinan wilayah pedesaan Jawa Barat, yaitu Rp 210 000. Secara umum pengetahuan gizi subjek tergolong cukup baik, yaitu $47.5 \%$ subjek termasuk kategori sedang, dan nilai rata-rata $64.3 \pm 17.6$.

Secara keseluruhan pada umumnya (modus) subjek menyatakan "suka" dan "sangat suka" pada semua jenis kelompok jajanan. Urutan kelompok makanan jajanan dari yang paling banyak hingga paling sedikit disukai subjek adalah buah, minuman, makanan digoreng, keringan asin, kue, dan jajanan sepinggan. Pada semua kelompok jajanan, minimal $60 \%$ subjek menjadikan rasa sebagai alasan utama dalam menyukai makanan jajanan, diikuti kemudian dengan harga (6\%-27\%). Sangat sedikit sekali subjek yang menjadikan aspek gizi sebagai alasan dalam menyukai dan memilih makanan jajanan (0-6\%). Subjek mengonsumsi makanan jajanan 36.5 kali dalam seminggu. Urutan makanan jajanan yang dikonsumsi dengan frekuensi paling tinggi hingga paling rendah adalah makanan digoreng, minuman, kue, jajanan sepinggan, dan buah.

Disarankan kepada setiap sekolah diharapkan memberikan materi mengenai pendidikan gizi lebih intensif lagi mengingat pengetahuan gizi subjek masih tergolong cukup rendah, di samping karena sangat sedikit sekali $(<6 \%)$ subjek menjadikan alasan gizi dalam pemilihan makanan jajanan.

\section{DAFTAR PUSTAKA}

[BPS] Badan Pusat Statistik Jawa barat. 2012. Berita Resmi Statistik. No. 04/01/32/Th. XIV.

Bruun $\mathrm{H}$ et al. 2009. Adult intake patterns are related to adult and chilhood socioeconomic status. The Journal of Nutrition. 19,13341.

Deni \& Dwiriani CM. 2009. Pengetahuan gizi, aktivitas fisik, konsumsi snack dan pangan lainnya pada murid sekolah dasar di bogor yang berstatus gizi normal dan gemuk. Jurnal Gizi Pangan, 4(2), 91-96.

Gharib N \& Rasheed P. 2011. Energy and macronutrient intake and dietary pattern among school children in bahrain: a cross-sectional study. Nutrition Journal 10,62.

Jennings A, Welch A, Sluijs EMFv, Griffin SJ, \& Casady A. 2011. Diet quality is indenpendently associated with weight status in children aged 9-10 Year. J.Nutr, 141, 453-459.

Khomsan. 2000. Teknik Pengukuran Pengetahuan Gizi. Departemen Gizi Masyarakat dan Sumberdaya Keluarga, Fakultas Pertanian, IPB, Bogor.

Maghubat et al. 2011. Food preferences and dietary intakes of Philipino adolescents in Metro Manila, The Philippines. Mal J Nutr, 17(1), 3-41.

Mukherjee M, Chaturvedi L, \& Bhalwan C. 2008. Determinants of nutritional status of school children. MJAFI, 64, 227-231.

Osei A, Pandey P, Spiro D, Nielson J, Sherstha R, Talukder Z, Quin V, \& Haselow N. 2010. Household food insecurity and nutritional status of children aged 6 to 23 months in Kailali District of Nepal. Food and Nutrition Bulletin, 31(4), 483-494.

Proverawati A, Prawirohartono E, \& Kunjjoro T. 2008. Jenis kelamin, pendidikan ibu, dan motivasi dari guru serta hubunganya dengan preferensi makan sekolah pada anak prasekolah di TK Universitas Muhammadiyah Purwekerto. Jurnal Gizi Klinik Indonesia, 5(2), 78-83.

Puspitawati H. 2010. Pengaruh sosial ekonomi keluarga terhadap pola asuh belajar. Jurnal Ilmiah Keluarga dan Konsumen. ISSN: 1907-6037, 46-55.

Rodrigo P, Ribas L, Serre-majem Li, \& Arnceta J. 2003. Food preference of Spanish children and young people: the end kid study. European Journal of Clinical Nutrition, 57. Suppl 1, 545-548.

Soekirman. 2011. Taking the Indonesian nutrition history to leap into betterment of the future generation: development of the Indonesian nutrition guidelines. Asia Pac J Clin Nutr, 20 (3), 447-451.

Syafitri Y, Syarief, H, Baliwati, Y.F. 2009. Kebiasaan jajan siswa Sekolah Dasar (studi kasus di SDN 
Amalia dkk

Lawanggintung 01 Kota Bogor). Jurnal Gizi dan Pangan, 4(3), 167-175.

Syarifah. 2010. Kebiasaan Jajan serta Kontribusi Energi dan Zat Gizi Makanan Jajanan terhadap
Kecukupan Gizi Siswa Sekolah Dasar (Skripsi). Mayor Ilmu Gizi Departemen Gizi Masyarakat, Fak. Ekologi Manusia. Institut Pertanian Bogor, Bogor. 